\title{
THE BRITISH NORTH AMERICAN BOOK TRADE IN THE 1840S: THE FIRST CRISIS
}

The subject of my paper this afternoon is the impact of the 1842 Literary Copyright Act upon the British North American book trade. As my title indicates, I believe that the 1840s witnessed the first of several book-trade crises during the past 130 years. No doubt many people today believe that the current crisis is the only one, but in fact it has developed in part because some of the problems which generated the first crisis were not satisfactorily resolved at that time nor throughout the next century. Indeed, one of my purposes today is to show that many practices and trends in the Canadian book trade had their origins in colonial times.

Before continuing with my subject, however, I want to explain what my connection has been with this topic. For some years I've been preparing a history of the book trade in Canada along the lines of Lehmann-Haupt's The Book in America. This history has grown out of my dissertation ${ }^{1}$ which studied some book-trade patterns between 1890 and 1940. During 1972-73, thanks to a Canada Council Leave Fellowship, I've been able to complete almost all my research on the book trade up to 1971. Among the materials I've assembled is a bibliography of some 2,000 items on people, events, and problems concerned with our colonial and dominion book trade. I've also started a checklist of the imprints of 18th and 19th century publishers, drawing chiefly on the important checklists of Tremaine, Hare and Wallot, Gagnon, Caniff, and Peel, among others; and of course the Checklist of Canadian Literature (rev. ed. 1972) by my colleague, Dr. R. E. Watters. As you know well, these scholars, along with H. Pearson Gundy and Gordon Roper, are among the handful of Canadians who have done work similar to mine. I am indebted to their researches and, I should add, to several others whom I have not mentioned.

I have tended to work backwards, because the information from the $1890 \mathrm{~s}$ onward is reasonably complete - once you discover where it's hidden. In the past year, for instance, I've been tracking down information dealing with the years 1750 to 1867 . This is a period about which few of us have had more than a few glimpses. While there are many gaps in my account of the first century, I think that I've been able to assemble a reasonably accurate picture of booktrade and printing and publishing conditions, and of our relations with the American and British book trades. Nevertheless, because I'm still progressing through this early period, some of the conclusions I shall present this afternoon

\footnotetext{
${ }^{1}$ George L. Parker, A History of a Canadian Publishing House: A Study of the Relation Between Publishing and the Profession of Writing, 1890-1940, Ph.D. Dissertation, University of Toronto, 1969.
} 
are tentative and open to revision. Now, however, much as I would like to tell you how and where I gathered my materials (and perhaps some of you who are working in related fields would also like to hear more), I must return to the topic.

I have divided my paper into three parts. First, some information about the book trade in the second quarter of the century. This will provide a background for the second part, which is an explanation of the way booksellers and legislators set about to fight some very restrictive clauses in the Imperial Copyright Act. Thirdly, I want to explore the consequences of the 1847 Foreign Reprints Act, which was passed to help the colonials get the books they wanted.

The first important account of the book trade in the British American Provinces came from William Lyon Mackenzie. He described in The Colonial Advocate for 6 April 1826 a pathetic state of affairs which foreshadowed future problems:

In all of Upper Canada Mr. Peter M'Phail, of York, is the only professional bookbinder, and there is not one concern that depends solely on the sale of books or of books and stationery, above Montreal . . . For booksellers' shops you must go to Montreal, Quebec, Halifax, or St. Johns [i.e., Saint John]; even in these large towns the trade is not carried on but in retail; if your bookseller has not the work you want, he will get it for you bye and bye, from New-York, Boston, or England. I am not sure that an extensive bookseller would thrive in Montreal; but with a good capital to enable him to give credit to the country stores, he might succeed in diverting to that city a large portion of the brisk trade which now goes to the United States. ${ }^{2}$

Let me restate Mackenzie's two points: in the colonies, bookselling is a precarious business, and secondly, there is a brisk trade with United States centres.

The precariousness can be illustrated by a brief reference to Joseph Howe's publication of Haliburton's An Historical and Statistical Account of Nova Scotia (1829). Howe printed this two-volume history in an edition of 3,000 copies $^{3}$ and was so certain of its success that he assumed all of its publishing costs. These were rather formidable, in keeping with the ambitious nature of the project. Type and lead cost $£ 32.10$; wages came to $£ 310.18 .5$; paper, plates, and duty on 336 copies sent to the United States came to $£ 391.18 .5$. Over the years he estimated his total debts for this work as something between $£ 1173^{4}$ and $£ 1300 .{ }^{5}$ Howe spent ten years paying off these debts. He had relied on "heavy sales in England, the United States and the other Provinces. None sold abroad,"6

2 [William Lyon Mackenzie], "Letter 97. On Printers and Publishers," by Peter Russell [pseud], The Colonial Advocate, 6 April 1826.

${ }^{3}$ Joseph A. Chisholm, "Hitherto Unpublished Letters of Joseph Howe," Dalhousie Review, XII (October 1932), 314.

${ }^{4}$ P.A.C., Joseph Howe Papers, vol. 33.

5 Ibid., vol. 33, Howe to Haliburton, 2 January 1841.

6rid., vol. 33, Annual Entry (1829). 
he said. In the late 1830s his office still contained 1,000 unsold copies which were being offered at half price. This is surely the classic example in the colonial book trade of a publishing disaster.

As for the "brisk trade" with the United States, the correspondence of both Howe and the firm of Neilson and Cowan offer evidence of such relations. Howe bought his type, presses and stationery from American firms. Neilson and Cowan were in constant communication with Carey \& Lea of Philadelphia in the late $1820 \mathrm{~s}$ and $1830 \mathrm{~s}^{7}$ In effect, the Quebec bookselling firm had a loose form of agency arrangement with Carey \& Lea. It was not what we understand by the term agency today. Neilson and Cowan would be given the exclusive right to dispose of individual titles for wholesale and retail distribution within their Quebec territory. These American productions did not carry the Neilson and Cowan imprint, however, since the number of copies imported was usually under twenty. And Neilson and Cowan had to contend with the most common problem Canadian agents have always faced: how to prevent the local competitor from importing the same title and selling it before the legitimate one even arrived at the agent's. ${ }^{8}$ In addition, the annual trade sales which were established in the 1820 s by Philadelphia and New York firms were patronized by colonial booksellers. For example, Mackenzie himself attended the 1837 New York spring trade sale, and brought home to his Toronto bookstore several thousand volumes. 9

However, the other side of this "brisk trade" with the United States was expressed by the schoolmaster Alexander Davidson, in a letter of 2 June 1828:

Nine-tenths of the books in use [in schools] , as far as I have had opportunity of observing, are from the United States, which is scarcely consistent with prudence, not to speak of their defects. The Board of Education indeed does not approve of their use, and the Europeans object to them, but it is in vain to contend with the imperious dictates of necessity. For several years no English books could be procured in this neighbourhood, so that I am led to believe that the supply from England is precarious, and not at all equal to the growing demands of the Province. ${ }^{10}$

This view was common to men who questioned American book imports on a more profound level than the economic one. Davidson, Strachan, and Ryerson were the vanguard of those who feared the cultural consequences of American books.

By the 1820 s, then, the importation of books and other supplies was a wellestablished pattern. There were, of course, similar relations across the Atlantic. Colonial booksellers - among them Howe, Neilson and Cowan, Mackenzie, Armour \& Ramsay, and Thomas Maclear - traded with British, and particularly Scottish, firms such as Oliver \& Boyd, Thomas Cadell, and Nelson's.

7P.A.C., Neilson Papers. See vol. 160 for the correspondence with Carey \& Lea.

${ }^{8}$ Ibid., vol. 160, Neilson \& Cowan to Carey, Lea, \& Carey, 9 October 1827.

9Charles Lindsey, The Life and Times of Wm. Lyon Mackenzie (Toronto: Randall, 1862), I, 401.

10 Alexander Davidson to Major Hillier, 2 June 1828, quoted in S. D. Clark, The Social Development of Canada (Toronto: University of Toronto Press, 1942), 282-283. 
To return to Mackenzie's 1826 article, we also find a comparison between the large quantity of American productions and the smaller number of colonial productions. "Very few books of any sort are printed in the colonies," Mackenzie states. While some of us would like to know how much he meant by the phrase "very few," our knowledge about Canadian and Maritime production in that decade seems to bear him out. Most of the works produced were government documents, religious and political pamphlets, almanacs, and some travel and statistical accounts.

Mackenzie pointed to another grievance which he, as a bookseller, experienced at first hand. This was the inept, and sometimes corrupt, colonial postal system. Postage rates were very high and they were paid by the receiver; consequently, books, reviews, and even pamphlets cost far more than their original retail price in England. Mackenzie advocated a system similar to the American postal system which, if implemented, would then permit British publishers to sell more competitively in Canada. In addition to the high rates, the British Government was reluctant to allow British books and periodicals to enter Canada via United States ports. Hence, during the winter months Lower and Upper Canada got no shipments of books from Britain. In 1836, therefore, the Upper Canada Assembly sent an Address to King William IV to request that British goods, including books, presses, type, and ink, be permitted free through American ports when destined for the Canadas. ${ }^{11}$

Between the late 1820 s and 1850 there were established many of the printing, publishing, and bookselling firms which dominated the trade throughout the mid-19th century: in Charlottetown, the Haszard family; in Halifax, Clement Belcher, Joseph Howe, the Cunnabell family, and James Bowes; in Saint John, J.\&.A. Macmillan; in Quebec, Joseph-Octave Cremazie; in Montreal, Ludger Duvernay, Armour \& Ramsay, Lovell \& Gibson, Beauchemin \& Valois, and Benjamin Dawson; in Toronto, Hugh Scobie, H.\&.W. Rowsell, George Brown, and Thomas Maclear. At least one of these firms was the precursor to a contemporary Toronto publisher: when Hugh Scobie died in 1853, the bookstore part of his establishment was bought by Thomas Maclear. Around 1858 or 1859 Maclear also took over Andrew Armour's Toronto store. Maclear sold his bookstore to Dr. William Chewett in 1863 (although Maclear's wholesale and publishing business continued for some years thereafter), and when Chewett retired in 1865 , his two younger partners William W. Copp and Henry J. Clark inherited the business. In 1873 Copp, Clark retired from the retail trade to concentrate on printing, publishing, and the wholesale trade. ${ }^{12}$ Back in the 1830 s and 1840s, however, most of these firms owned a printing office, published newspapers, books, journals, almanacs, and operated a wholesale and retail store, as did Armour \& Ramsay. But specialization was just around the corner. Lovell \& Gibson, who established their partnership in 1837 , concentrated on printing

11 Great Britain, Parliament, House of Commons, Upper Canada, Copy of an Address of the House of Assembly of Upper Canada to His Majesty, Respecting the Commerce and Trade of that Province, \&c. (London: [H.M.S.O.], 1836).

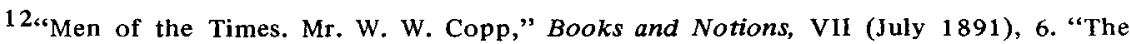
Late Henry J. Clark," Books and Notions, VII (March 1892), 8. "Death of Mr. Maclear," Bookseller and Stationer, XIV (January 1898), 2. These articles contain discrepancies about the dates of the firms' changes. 
and publishing, and never, as far as I can determine, had a bookstore.

Several of these firms had branches: Armour \& Ramsay, most notably, had branch stores in Kingston, Toronto, and Hamilton. The Lesslies and the Rowsells of Toronto also had Kingston branches. ${ }^{13}$ Furthermore, colonial booksellers traded extensively with each other, as the notices in newspaper advertisements indicate. Those peculiar title-page imprints, which sometimes contain several booksellers' names, are also evidence of inter-provincial trade relations. ${ }^{14}$ Some of these stores seem to have been well-stocked. Lindsay reported that Mackenzie's bookstore at the time of the 1837 rebellion had some 20,000 volumes. ${ }^{15}$ If I read his estimate correctly, Joseph Howe believed his bookstore in 1841 was worth about $£ 1,400 .{ }^{16}$ Even more impressive was the book establishment of Armour \& Ramsay in Montreal. I found in the British Museum last year a 36-page Catalogue of Books . . . for Sale . . . , a pamphlet printed by Armour \& Ramsay in 1836 , the year in which they began an extensive trade with British houses. The Catalogue lists thousands of contemporary, standard, and classical titles under the headings of History \& Biography, Science \& Philosophy, Medical Works, Novels, Poetical Works, Theology, Annuals, School Books, French Books, and in addition Engravings and Stationery. ${ }^{17}$ The titles are evidence both of Armour \& Ramsay's aggressiveness and of their estimation of colonial literary tastes.

By the 1840 s the provinces were sufficiently populous and prosperous to support a more substantial book trade, and some of the statistics we can assemble certainly contradict the statements of travellers in the 1830s like Mrs. Jameson and Isaac Fidler. Montreal, the undisputed centre of the book trade for the Canadas, if not for all the colonies, had a population of 55,000 . The Montreal Directory for $1843-44$ lists 16 booksellers, stationers, and bookbinders, 15 printing offices, 2 engravers, and one type-foundry agency. ${ }^{18}$ Toronto's directories, unfortunately, did not list firms conveniently by trade, so my figures for this city may be open to question. With a population of 25,000 in 1846-47, Toronto had 5 bookselling and stationery firms, 8 bookbinders, about 38 individual printers, and at least 7 printing offices. ${ }^{19}$ I think we could

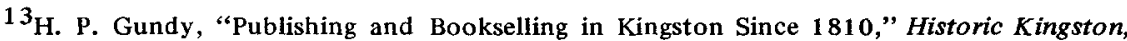
No. 10 (1960-1961), 29-30.

${ }^{14}$ The title page of George Renny Young's On Colonial Literature, Science and Education contains the following information: Halifax, Nova-Scotia: Published by J. H. Crosskill \& Co., Market square, and sold by C. H. Belcher, A. \& W. Mackinlay, and A. W. Godfrey, Halifax; J. Dawson, Pictou; W. L. Avery, St. John, N. B.; T. Cary \& Co., Quebec; Armour and Ramsay, Montreal and Kingston; W. Rousell, Toronto; H. Stamper, P.E. Island; and M’Murdo \& Co., St. John's, N. F. 1842.

15 Lindsey, II, 98.

16 Joseph Howe Papers, vol. 33.

17 Armour \& Ramsay, Catalogue of Books, in the Various Departments of Science and General Literature, For Sale by Armour and Ramsay (Montreal: Montreal Gazette [printed], 1836), 18p.

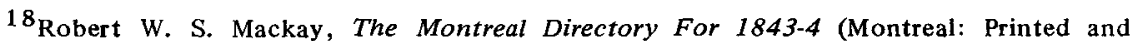
Published by Lovell \& Gibson . . . and by Robert W. S. Mackay [1843]), 240-241, 300-301.

${ }^{19}$ Brown's Toronto City and Home District Directory. 1846.7 (Toronto: Printed and Published by George Brown, 1846). 
find comparable numbers for Quebec City, Saint John, Charlottetown, and Halifax. The latter city, with a population of 20,000 in the 1840 s, had at least 4 bookstores and about 7 printing of fices. Of course, the situation in smaller centres and in rural districts was far different. Nevertheless, small towns often had a newspaper, and merchants carried books as part of their general stock. There were book peddlers, too. Sometimes they were itinerant missionaries, such as Walter Johnstone who traversed P.E.I. in the early 1820 s distributing free titles from the Scottish Missionary Society. ${ }^{20}$ In later decades the peddlers were often Yankees who sold books published by subscription only. ${ }^{21}$

Colonial printing offices could survive by means of their local work, such as newspapers, job work, and government contracts. However, booksellers simply could not rely on colonial publications to keep their shelves stocked and themselves in business. They did, of course, carry related lines like stationery, fancy goods, pens and ink, charts and engravings. But if they were to stock books and periodicals, they had to import from the United Kingdom and the United States.

I want to digress for several minutes from my description of the colonial book trade in order to explain very briefly how events in the British and American trades affected the British North American trade.

There is no doubt that British Americans eagerly desired the writings of British authors, but there were economic and physical disadvantages about getting those works to this side of the water. Because the British book trade kept its runs small and catered to the carriage trade, it kept its prices artificially high. ${ }^{22}$ Even when cheap series were inaugurated from the 1820 s onward - to facilitate the clients of the Mechanics' Institutes - the series titles, while valuable and utilitarian, were not always the latest books but those which probably had exhausted their high-priced-edition sales. Furthermore, ordering and shipping across the Atlantic was a slow business. For instance, Neilson's in Quebec regularly ordered two major shipments a year from their Scottish correspondents, one in the fall before the ice closed the St. Lawrence and one in the late winter as soon as the ice broke up. French-language firms like E. R. Fabre ${ }^{23}$ of Montreal, which regularly ordered legal, theological, literary works, and textbooks from France, may have had similar problems over tardy shipments. Even with faster ocean service after 1840, there were problems of overland shipments. By the 1850 s, however, the development of railroads in the eastern United States and the Canadas began to reduce some of these problems. Furthermore, as Mackenzie noted, British and colonial postal rates were very high.

On the other hand, trade with the United States was far simpler. While

\footnotetext{
${ }^{20}$ Walter Johnstone, Travels on Prince Edward Island . . in the Years 1820-21 (Edinburgh: Printed for David Brown, 1823), 20, 120-121.

21 Susanna Moodie, Life in the Clearings (Toronto: Macmillan, 1959), 289. Also: Michael Gonder Sherk, Pen Pictures of Early Pioneer Life in Upper Canada, By a "Canuck" [pseud], (Toronto: Briggs, 1905), 83-84.

${ }^{22}$ Richard Altick, The English Common Reader (Chicago: University of Chicago Press, 1957), 263-264.

${ }^{23}$ See Advertisement for E. R. Fabre in La Minerve, 17 septembre 1827, 4. Presumably books ordered from France had to be transmitted by British ships.
} 
there were not as many American authors as British ones, the Americans had overcome this drawback by pirating British books and periodicals, printing these in huge quantities, and selling them cheaply. ${ }^{24}$ American publishers, hardly concerned with a carriage trade, catered to the needs of a large population, and its printers demanded and got protectionist copyright laws. It's not surprising that the inexpensive American reprints found their way into the hands of the Canadian consumer. Books could be sent cheaply by American post. Thus Carey \& Lea of Philadelphia would ship a consignment to Neilson's in Quebec as far as Burlington or St. Albans, at which places the shipment would then be transferred to barges bound for St. John's (the customs port-of-entry), and thence up the river. ${ }^{25}$

Did it matter to the Canadian buyer whether the imprint was American or British? Perhaps we can't answer this accurately; nevertheless, a comparison of British and American prices may explain how the choice was often made. In 1843, J. H. Tebbetts, a Montreal bookseller, explained to a Legislative committee that C. P. R. James's new novel Morley Errstein was published in England at $£ 2.10$ sterling; but with the postage rate added, its price in Montreal became $£ 4.10$; whereas he could sell the American reprint for $1 \mathrm{~s} .10 \frac{1}{2} \mathrm{~d}$. While explaining this situation, Tebbetts claimed to be the leading Montreal importer of reprints, that he paid postal rates on these of $£ 400$ per annum, and that the annual subscriptions for American reprints in this Province was about $£ 14,000$ currency. 26

Knowing of this situation, British authors and publishers tiied various methods to protect their interests in the United States. The very important visit of Dickens to the States in 1842, for example, was an attempt to use courtesy, ethics, and personal appearances to gain what the laws would not give. ${ }^{27}$ In British America, of course, the British in theory could protect themselves by means of the imperial copyright laws and the courts. In actuality, the British authorities had a difficult time controlling the importation of British copyrights into the Provinces. Meanwhile, from the 1840 s to the 1890 s, the British pressed for an international copyright agreement with the United States. ${ }^{28}$ In this they were supported by most American authors and many of the respected publishers. But reciprocal copyright bills were generally frustrated by the lobbying of the powerful printing unions. At the same time, Anglo-Canadian and CanadianAmerican book-trade relations were also coloured by those attempts to reach an Anglo-American agreement.

The 1840 s were not the first time that copyright had been discussed in the

${ }^{24}$ Helmut Lehmann-Haupt, The Book in America, 2nd ed. (New York: Bowker, 1952), 109-112.

25 Neilson Papers, vol. 165. See the correspondence (1 827-1836) between Neilson \& Cowan and Chauncey Goodrich, a Burlington, Vermont bookseller.

${ }^{26}$ Canada (Province), Legislative Assembly, Sessional Papers, No. 2 . . of the Journals, 1843 ([Kingston: Edward John Barker, 1844]), Appendix PP. "Report of the Select Committee Appointed to Enquire into the Effect of the English Copyrights Act ....." [1 $1 \mathrm{p}$ ]

${ }^{27}$ Edgar Johnson, Charles Dickens, His Tragedy and Triumph (New York: Simon \& Schuster, 1952, I, 375-376.

${ }^{28}$ Lehmann-Haupt, 201-211. 
colonies. In them, as in the United Kingdom, the basic Literary Copyright Act was that of 1709 ( 8 Anne Cap. 19). This was amended by a number of acts and by court interpretations throughout the 18th century. Due to the growth of the book trade and of professional authorship, the copyright laws were a tangle of interpretations and anachronisms. Hence, serious attempts were made from 1810 onward to update and consolidate the copyright laws. But the only legislative privilege the colonies had in copyright matters was to propose purely local acts. The first local copyright Act was passed in 1832 by Lower Canada (2 Will IV. Cap. 53), and it gave copyright protection for a maximum of 42 years, required the deposit of copies in the Registrar's Office, and imposed penalties on infringements. Nova Scotia passed an Act of similar content in 1839 (2 Vict. Cap. 36), and the first book copyrighted in Nova Scotia was Haliburton's The Letter Bag of the Great Western (1840). Upper Canada did not have a Copyright Act until after the Union of 1841, when the 1832 Lower Canada Act was repealed to be revised as a new Act for the Province of Canada (4\&5 Vict. Cap. 60). The first work copyrighted under this Act was Robert Christie's first two volumes of the History of Canada. Thus by 1841 two provinces had passed local copyright acts while New Brunswick, Prince Edward Island, and Newfoundland had not. In the next year, the new Imperial Literary Copyright Act (5\&6 Vict. Cap. 45) came into force. This Act was framed by men whose first concern, naturally, was the protection of the British book trade and British authors. Hence booksellers and circulating libraries in the United Kingdom were no longer permitted to buy cheap foreign reprints of English copyrights. For decades these works had competed unfairly with the expensive and relatively small editions of English publishers.

Almost immediately, The Publishers' Circular (the organ of The Publishers' Association) called for the exclusion of foreign reprints from the Colonies as well:

At present they purchase almost exclusively these pirated American and French copies of English books, both for libraries and individuals. The publishing and export business houses at home have only to put their foreign agents on the qui vive, and we shall soon have to report the same beneficial effects in our colonial possessions, which, with gratitude to the legislature, we now announce that we are experiencing at home. ${ }^{29}$

As a result, Parliament then invoked Sections 15 and 17 of the 1842 Act, which prohibited pirated reprints from entering British colonies and placed a duty of 35 per cent on original American publications. On 3 November 1842 the General Post Office sent a directive to the Halifax Post Office. It declared that the principal publishers of London (those mentioned are Longman, Murray, Colburn, C. P. R. James, and Dickens) had requested a ban on the New York New World ${ }^{30}$ which was pirating the works of English authors. From time to time in the next five years, similar bans were placed on the New York Albion,

29"Literary News," The Publishers' Circular, V (1 October 1842), 273.

${ }^{30}$ P.A.N.S., Nova Scotia, Colonial Office, R. G. 24. no. 59, Post Office, Letter from G.P.O. London to G.P.O. Halifax, 3 November 1842. My thanks to Miss Phyllis Blakeley who brought this item to my attention. 
and Brother Jonathan. The "ban" was effected by charging letter rates for these so-called "newspapers" and "pamphlets" and thereby discouraging their shipment into British territory.

The prospect of losing American books and periodicals aroused booksellers and readers throughout the Provinces. Their outcry precipitated the first crisis in the British North American book trade. On 20 July 1843 the Lieutenant Governor of New Brunswick complained about the cutoff to Lord Stanley, the Colonial Secretary. ${ }^{31}$ In August The Literary Garland noted the universal complaints of readers who had received the introductory numbers of Martin Chuzzlewit in the American-reprint version, and who would no longer be able to follow the novel. The Garland hoped this situation would induce British publishers to issue competitive cheap editions for colonial circulation. ${ }^{32}$ I now want to discuss the two ways in which the crisis was met: the attempts of the Provincial assemblies to press for changes in the copyright laws, and the business activities of Armour \& Ramsay.

In the autumn 1843 Assembly of the Province of Canada, a Select Committee was appointed to report on the book situation. Under the chairmanship of John Simpson, the Committee requested the leading importers, publishers, and booksellers of the Province to submit evidence. The printed Report included the replies of ten booksellers, ${ }^{33}$ and of a correspondent from New Brunswick. This Report remains a tribute to the intelligence and perspective of colonial legislators.

The booksellers were asked a series of questions. Did they prefer importing American or British editions? Had the Imperial Act changed importing patterns? Would the culture of the Province be affected for the worse by the Imperial Act?

The booksellers were of mixed feelings about the importation of American reprints. Hugh Scobie was certain that the colonists could not afford new British books, and would get the American reprints by one means or another. He felt that "the exclusion of these Reprints is a shortsighted policy which can benefit nobody, while it deprives many of the greatest mental enjoyment they have been accustomed to rely on in the Colony, and which cannot be supplied by any other means within their reach." 34 Thomas Cary of Quebec took a similar line. "The repugnance to the unscrupulous piracy of the American publishers apart, that piracy has done more to create a literary taste in Canada than English legislation has done since the country became an appendage of the British Crown." 35

At the same time, H. \& W. Rowsell welcomed the move by some publishers

${ }^{31}$ New Brunswick, Legislative Council, Journals, 1847 (Fredericton: John Simpson, 1847), 22-23. Copy of a Despatch from Lt. Gov. W.M.G. Colebrook to Lord Stanley, 20 July 1843.

32 “Our Table," The Literary Garland, I n.s. (August 1843), 384.

${ }^{33}$ The Booksellers: James Macfarlane, Kingston; James Harrison, Belleville; Hugh Scobie, H. \& W. Rowsell, and Lesslie Brothers, Toronto; J. H. Tebbetts, William Greig, Armour \& Ramsay, Montreal; Thomas Carey [sic] and William Cowan, Quebec City.

${ }^{34}$ Appendix PP, [p. 2].

35 Ibid., [p. 6]. 
like John Murray to produce cheap editions for the colonies. They claimed that they could now import Murray's Quarterly Review at 3s. per number. This was far cheaper than either the 8s. 6d. of the English edition or $4 \mathrm{~s} .4 \frac{1}{2} \mathrm{~d}$. (including postage) of the American reprint of the Quarterly. The Rowsells predicted that if the English continued to print cheap colonial editions, there would be great benefits to British publishers and authors alike. ${ }^{36}$ William Greig, however, pointed out that most of Murray's titles were those whose demand was exhausted. Furthermore, the $2 \mathrm{~s}$. price was the equivalent of $3 \mathrm{~s}$. in Canada, whereas the 25-cent American reprint sold for 1s. 101/2d. in Canada. The American reprint editions, therefore, were still a bargain. Yet Greig admitted that Colonial reprints of British periodicals would be beneficial but for the absurd Post Office rates on all unstamped printed matter. ${ }^{37}$

The Select Committee therefore reached the following three conclusions:

1st. That the importation of English Literature direct from Great Britain, has not at all increased under the operation of the English Copyrights Act. 2nd. That the free admission into this Province of American reprints of English Works of Art and Literature, could not lessen the profits of English Authors and Publishers; because, although the reading population of the Province is great in number, yet the circumstances of the population generally are so limited in their means, that they are unable to enjoy English Literature at English prices; that owing to that inability to pay for such Works of Art and Literature there has never been a demand for those Works, and consequently no supply.

The final conclusion is even more significant from a cultural point of view:

3rd. That the exclusion of American Reprints of English Literature, if possible, would have a most pernicious tendency on the minds of the rising generation, in morals, politics, and religion; that American Reprints of English Works are openly sold, and on the tables or in the houses of persons of all classes in the Province; that a law so repugnant to public opinion cannot and will not be enforced; that were that exclusion possible, the Colonists would be confined to American Literary, religious, and political Works, the effect of which could not be expected to strengthen their attachment to British Institutions, but, on the contrary, is well calculated to warp the minds of the rising generation to a decided preference for the Institutions of the neighboring States, and a hatred deep rooted and lasting of all we have been taught to venerate, whether British, Constitutional, or Monarchical, or cling to, in our connection with the Parent State. ${ }^{38}$

What other steps, we may ask, did colonial booksellers take to control this situation? Two activities of Armour \& Ramsay demonstrate how that firm ${ }^{36}$ Ibid., [p. 2].

${ }^{37}$ Ibid., [p. 4].

${ }^{38}$ Ibid., [p. 1]. 
hoped to withstand American competition and simultaneously to increase British trade in the colony. (Their business principles, possibly, have some relation to their conservative political views.) They tried for agency arrangements and they tried for reprint rights.

I have already referred to the importation of American reprints of British magazines. If these could be stopped by the Post Office, and if the British could be persuaded to print cheap editions of their periodicals, then the Canadian trade might benefit as well as the British. On 7 March 1843 Armour \& Ramsay wrote to Blackwood \& Son, to suggest that the Scottish firm produce a cheap edition of Blackwood's starting on 1 July. Armour \& Ramsay would be pleased to handle its colonial distribution. ${ }^{39}$ The plan was in fact begun by early 1844 . Along with Thomas Cary, Hugh Scobie and the Rowsells, Armour \& Ramsay advertised in late 1843 that they would offer the public ten British magazines, quarterlies, and reviews at a competitive price with the American reprints. ${ }^{40}$ The advertisements were feelers since the firms wanted half a year's payment in advance with the receipt of the first number. These cheap editions were run off on cheap paper after the regular run, and were expressly intended for colonial circulation only. They were shipped so as to arrive before the American reprints could circulate in Canada. A similar arrangement was adopted for several cheap series of books. Already in 1843, Armour \& Ramsay were selling Robert Cadell's Peoples' Edition of the Waverley Novels, issued in monthly parts, at prices to compete with pirated American reprints of Scott. ${ }^{41}$ Then in 1844 Armour \& Ramsay persuaded John Murray to permit them to sell the Murray Home and Colonial Library Series at 2s. 6d., local currency, which brought these prices in line with the $2 \mathrm{~s}$. $6 \mathrm{~d}$. sterling price in Britain. ${ }^{42}$ The Literary Garland saw these trends as encouraging signs that the British publishers would not let the Americans ruin the value of copyrights in the Provinces. ${ }^{43}$

It was easier to make agency arrangements for "colonial editions," which were manufactured in the United Kingdom, than to get reprinting rights in the colonies. In fact, I suspect the majority of reprint editions were textbooks. Armour \& Ramsay printed at least three textbooks in 1843. And by 1845 , Armour \& Ramsay announced that they were manufacturing Canadian editions of the school texts recommended by the National Board of Education in Ireland. ${ }^{44}$ These books became known in the Province as the British American School Books. As far as I can determine, Hew Ramsay continued to print these Canadian editions of the National School Books until his death in 1857.

Another means of facilitating trade with Britain was to publicize the works of the British press in Canada. American reprints of British periodicals naturally

${ }^{39}$ National Library of Scotland, MSS. No. 4063, Armour \& Ramsay to Blackwood \& Sons, 7 March 1843. My thanks to Professor Carl Klinck for bringing this letter to my attention.

${ }^{40}$ Armour \& Ramsay Advertisement in Chronicle and Gazette and Kingston Commercial Advertiser, 13 December $1843,1$.

41 “Our Table," The Literary Garland, I n.s. (September 1843), 432.

42 “Our Table," The Literary Garland, II n.s. (July 1844), 336.

${ }^{43}$ Ibid., 336.

44“"Our Table," The Literary Garland, III, n.s. (July 1845), 336. 
did not include the publishers' lists which were inserted as advertising material in the British editions of those periodicals. Hence in 1845 Armour \& Ramsay issued four numbers of Armour \& Ramsay's Literary News Letter and General Record of British Literature. ${ }^{45}$ This is probably the first book-trade journal in British North America. It was a very modest catalogue, no doubt, since it was chiefly a record of Armour \& Ramsay's imports from Britain, as well as a list of current publications in the United Kingdom, and a minimal amount of gossip. Although I have seen no issues of this Literary News Letter, I suspect the Montreal firm could get all its information from current numbers of The Publishers' Circular.

Such efforts did not go unnoticed or unappreciated by colonial readers. The Literary Garland observed in October 1846:

The Canadian public do certainly owe to Messrs Armour \& Ramsay a very heavy debt of gratitude for their unwearied and persevering efforts in providing for the million such an abundance and variety of cheap reading and thereby preventing the further spread of that ephemeral trash with which we have been lately overwhelmed. ${ }^{46}$

The situation was much the same in New Brunswick - or even more aggravated, since ready money was scarcer for books than in the Canadas. The New Brunswick correspondent to the Select Committee (whose name, unfortunately, was illegible to the printers), estimated that the total amount of books of all descriptions imported to New Brunswick from England in a year would not value $£ 500$, while the value of new works only would be under $£ 100.47$ Furthermore, New Brunswickers had to get their English books from Halifax, whence they were carried overland, and this procedure caused not only delay but extra charges.

But the main point of the writer's protest - like that of the Canadas - was that educational and cultural progress was severely damaged by the present arrangements. It was, the New Brunswicker said, "not a question of cheap or dear reading - but of cheap reading, or not reading at all."48

The British Americans got no satisfaction for three years. On 21 December 1843 Lord Stanley pointed out that the Imperial duty on books was actually 7 per cent ad valorem, a substitution for the earlier 30 per cent ad valorem duty, and he required more evidence before any remedy could be made. ${ }^{49}$ On 27 November 1845, Lord Stanley told the Nova Scotians:

Even if it could be established that English Authors have not benefitted by the enforcement of the Copyright Laws, it is felt that it would be impos-

\footnotetext{
45“"Our Table," The Literary Garland, III, n.s. (September 1845), 431.

46“"Notices of New Works," The Literary Garland, IV n.s. (October 1846), 471.

${ }^{47}$ Appendix PP. [p. 20].

48 Ibid., [p. 9 ].

${ }^{49}$ Canada (Province), Legislative Assembly, Journals, 1844-1845 ([ Montreal: Rollo Campbell, $1845]), 65$.
} 
sible to sanction a departure from the principle laid down, as it is conceived to be a principle not of expedience but of justice. 50

However, a surprise event took place. The British election of 1846 returned the Whigs to power and gave new hopes for copyright adjustments. Consequently, the Provincial Legislatures stepped up their campaigns. The Canadian Assembly examined New Brunswick's address on reduced postal rates and relaxation of the Copyright Acts. In Nova Scotia a committee under George Renny Young again investigated the problem of copyright and quoted extensively from the Province of Canada's Select Committee Report of 1843. The new British Ministry was prepared to allow an important amendment to the 1842 Act. In London the matter was treated in a clandestine way. On 5 November 1846, the new Colonial Secretary, Earl Grey, wrote the Provinces that the Imperial Government would prepare an amending act to allow the colonies to obtain cheap reprints "on better terms than it is at present." 51 This phrase meant, of course, importation from the United States. Grey warned, however, that British proprietors would have to be protected by responsible measures from each colony: that is, each Province would have to pass an Act to supervise the collection of a special $12 \frac{1}{2}$ per cent duty which would be in effect a royalty. The amendment was the Imperial Copyright Act of 1847 (10 \& 11 Vic. Cap. 95), usually known as the Foreign Reprints Act, constructed for the peculiar situation of the British North American Provinces only. This Foreign Reprints Act brought no comment from The Publishers' Circular or the literary magazines; their silence may have been due to either ignorance of the Act or a belief that the duties on each reprint crossing the border would be collected faithfully. The duties were not faithfully collected. In fact, it took about ten years for the British and Canadians to realize how much economic and cultural harm the Foreign Reprints Act had caused.52

For the moment, however, the Colonial Legislatures quickly took advantage of the Imperial Amendment to pass similar legislation. New Brunswick was the first to send an Act to the Colonial Office. Speaking on behalf of British booksellers and publishers, the Board of Trade rejected this first provincial

\footnotetext{
${ }^{50}$ Nova Scotia, House of Assembly, Journal, 1846, Appendix No. 31 ([Halifax:] Gossip \& Coade, 1846), 104.

${ }^{51}$ Canada (Province), Legislative Assembly, Appendix No. 1 to the Sixth Volume of the Journals, 1847 (Montreal: Rollo Campbell, 1847), Appendix K, Earl Grey to Earl Cathcart, 5 Nove mber 1846.

52 "Literary Intelligence," The Publishers' Circular, XIX (15 November 1856), 457-458. "We should like to know whether, when the [Foreign Reprints] Act was passed, either British authors or publishers were consulted about it, or any enquiry made of them whether they were willing to yield up the rights they possessed under the Copyright Act ...." 458 . See also:

“Literary Intelligence," The Publishers' Circular, XX (1 5 September 1857), 393-394.

"The permission to import prohibited books on any such terms is altogether and obviously so unjust and contrary to all the principles of Commercial Legislation, that it is scarcely worth while considering defects of detail in carrying it out," 393. "The great advance in our colonies during the last few years makes the value of copyright in our various dependencies one of immense importance to all connected with literature ....," 394.
} 
Reprints Copyright Act with schoolmaster severity, ${ }^{53}$ and then circulated its comments to the other provinces in order to show what kind of act the Imperial Parliament was prepared to allow. There were problems over wording, over lists of books to be excluded from the Colonies, over collection of duties, whether the rate should be determined by the price of the British or the American edition, and even disagreement over the definition of a book. ${ }^{54}$

In 1847 the Canadian Assembly passed "An Act to Extend the Provincial Copyright Act to Persons Resident in the United Kingdom on Certain Conditions" - the very title is sinister. It was rejected because it was framed upon a "totally different principle" than that of the Imperial Foreign Reprints Act. The Canadian Act insisted upon re-publication in the Colony as the basis of copyright protection. It has, therefore, the distinction of being the first of many similar Dominion Acts which were rejected by the British Government as Britain and Canada developed contrary positions on copyright. The Privy Council for Trade explained that they did not:

perceive the justice of the distinction which the Canadian Legislature makes between works printed and published in England only, and works re-printed and published in Canada. So far as they have the means of judging, they are of opinion that an edition for the Colonial market could be printed here more cheaply than in Canada. To protect works re-printed there, and to leave all others unprotected, would, therefore, fail to secure the advantages which are desired on all hands, namely, cheap publications, of a legitimate character, for the Colonies, and the repression of the illicit importation of pirated editions. ${ }^{55}$

In 1848 New Brunswick and Prince Edward Island had their Acts accepted; Nova Scotia's was accepted in 1849; and Newfoundland's in 1850. The Canadian Assembly tried again twice in 1850 before an acceptable Canadian Foreign Reprints Act was put into effect.

What can we conclude about the Foreign Reprints Act? What did it accomplish immediately? What were its long-term consequences? Did it help or hinder colonial authors? The answers, as far as I can assemble them, are riddled with ironies.

The immediate effects are easy to list. Booksellers began to import cheap American reprints in great quantities. In 1848, when J. \& D. Sadlier established their Montreal book store, and advertised their stock of over 20,000 volumes, they pointed out to customers that they had direct relations with their New York firm. They could thereby offer Canadian customers American books at

\footnotetext{
${ }^{53}$ New Brunswick, Legislative Council, Journals, 1847 (Fredericton: John Simpson, 1847), Appendix, cxiii-cxiv.

${ }^{54}$ Nova Scotia, House of Assembly, Journal and Proceedings, 1848 ([n.p.n.d.]), Appendices 9 and 32.

${ }^{55}$ Canada (Province), Legislative Assembly, Journals, 1849 (Montreal: Rollo Campbell, [1849]), Appendix N.
} 
New York prices. ${ }^{56}$ This may be the first instance of a Canadian book firm with an American outlet.

The economic boom of the 1850 s was reflected in the availability of books, the rising quality of bookstores, descriptions of well-stocked Mechanics' Institutes, and, despite the unfortunate end of The Literary Garland, the appearance of new literary magazines in most of the Provinces. Describing the literary situation of the Canadas in the early 1850s, Mrs. Moodie recorded in Life in the Clearings (1853):

The piracies of the Americans have realized the old proverb, 'That 'tis an ill wind that blows nobody any good'. Incalculable are the benefits that Canada derives from her cheap reprints of all the European standard works, which, on good paper and in handsome bindings, can be bought at a quarter the price of the English editions. ${ }^{57}$

In that same year, she reported in the preface to Mark Hurdlestone:

There is now no lack of books in Canada, of money to purchase them, and persons to read and understand them. The reading class is no longer confined to the independent and wealthy: mechanics and artisans are all readers when they have time to spare ...58

The long-term effects are more difficult to analyse. Ultimately these effects concern the development of agency publishing and the nature of copyright legislation. If the bookseller had a temporary advantage from the Foreign Reprints Act, Canadian publishers and printers did not. Perhaps I should qualify these words and say that, in spite of Armour \& Ramsay's efforts in this direction, the re-publishing and re-printing industry did not benefit. Here are some of the reasons: the British trade controlled the production and marketing of books within the Empire from London, although there were signs in the 1840s that American cheap-book production would force a British retreat in these provinces. But the British did not understand or really grasp the importance of cheap books to all North Americans. At the same time, the British trade feared that Canadian reprints of British copyrights would mean loss of sales to the British trade, and that these Canadian reprints might even find their way to Britain which I think was a very dim possibility. Hence, Mrs. Moodie noted in Life in the Clearings that the local publishing trade hardly had a chance:

Of books published in the Colony, we have very few indeed; and those which have been issued from a Canadian Press have generally been got out, either by subscription, or at the expense of the author. It is almost impossible for any work published in Canada to remunerate the bookseller,

${ }^{56}$ Robert Mackay, The Montreal Directory for 1849 ... (Montreal: Lovell \& Gibson, 1849), D. \& J. Sadlier Advertisement, 272.

${ }^{57}$ Susanna Moodie, Life in the Clearings (Toronto: Macmillan, 1959), 209.

58 Ibid., 289. 
while the United States can reproduce reprints of the first writers in the world, at a quarter of the expense. 59

In 1864 the Rev. Edward Dewart had the same complaints about colonial literary publications being swamped by foreign literature, and he bitterly blamed the booksellers for this state of affairs. ${ }^{60}$ Yet we should remember that these complaints were made in a period when the annual number of Canadian titles had increased significantly over the number published in the 1840 s.

Furthermore, two developments in the 1850 s and 1860 s, one for the worse, one for the better, brought about significant changes in the colonial publishing situation. One development, for the worse, was that British authors more and more tended to make private arrangements with responsible American publishers in order to receive a "gratuity" for the pirating of their works in the United States. Since British authors as a rule would not or could not make similar arrangements with Canadian booksellers, the American publishers naturally began to include the Canadian territory in their American markets. After all, colonial booksellers could legally import pirated British copyrights. And during the $1860 \mathrm{~s}$, when it became customary for American authors to receive imperial copyright protection, Canadian publishers couldn't retaliate by pirating American copyrights. Why didn't British authors make arrangements more often with Canadian houses? Did American publishers object - as they did in the twentieth century - to such deals up north? Was the Canadian market too small? Should we believe, as some Americans claimed later in the century, that the Canadian market in books was trifling? Yet in the 1880s and 1890s there was an AngloAmerican struggle for the Canadian market, during which the Americans claimed it didn't exist and the British ritually lamented its loss. This was the market which, in the first decade of the twentieth century, could absorb from 10,000 to 30,000 copies of Ralph Connor's novels. ${ }^{61}$

The other development, for the better, was that by the Civil War, Canadian printing costs and the quality of Canadian productions were competitive with the American industry's products. At this point, the Foreign Reprints Act became a positive menace to Canadian printing and publishing. From 1868 until the turn of the century, first John Lovell and Graeme Mercer Adam, and then a host of others including Prime Minister John Thompson (himself the son of a Halifax printer and bookseller), argued for a Canadian license to reprint British and American copyrights for the Canadian market. They saw that licensing, or a manufacturing clause, was the only way of fighting the Foreign Reprints Act. But it was almost too late in the 1890 s to change the flow of American productions in to Canada.

Now, for one of those paradoxes of the 19th century. Behind the conflicts over re-printing and re-publishing was the clash of British free-trade principles with Canadian views on protection. The British free-traders in the publishing

$59_{\text {Ibid., }} 289$

${ }^{60}$ Edward Hartley Dewart, Selections from Canadian Poets . . . (Montreal: Printed by John Lovell, 1864), xiv-xv.

${ }^{61}$ Gordon H. Allison, The Westminster Company, M. A. Thesis, University of Toronto, 1962, Chapter IV, 27-45. 
world wanted to send their products to Canada. Ironically, too, American protectionist manufacturers wanted to send their books to Canada. In terms of books, Canadians were unable to combat both American and British export practices. We could limit these practices, but we couldn't stop them.

There was also a clash over the principle of copyright. It was already there in the rejected 1847 Canadian Act. Basically, the British attitude was that copyright was a benefit to serve the author first of all. However, some provincial legislatures, and later the Dominion government, tended to support the view that copyright was a monopoly protection for the manufacturer. One reason for this anachronistic Canadian viewpoint - which got sanctified in Macdonald's National Policy - was that the printers were the most aggressive and articulate and influential voices in the 19 th century book trade.

Sometime between Confederation and 1900, the Canadian book trade had to evolve into an agency-publishing business. The direct legal cause for this situation was the 1847 Foreign Reprints Act which unintentionally made certain that the Canadian trade would be limited in its original and reprint publishing of foreign authors, and therefore be dependent upon two foreign markets for a large proportion of its books. It is no co-incidence that by 1900 , six years after the repeal of the Foreign Reprints Act, a new Canadian Copyright Act (63-64 Vict. Cap. 25) established the legal basis for agency publishing in 20th century Canada. In spite of American economic aggressiveness, then, there was no conspiracy as we are sometimes led to believe these days. It was an understandable short-sightedness which permitted the Americans to help themselves to the Canadian market. The Canadian public agreed to this situation, and bought American-manufactured books.

And, finally, did the copyright discussions of the 1840 s help or hinder the colonial author? In this connection, we should remember that both the Maritimes and the Canadas had their first significant literary movements around 1840. Colonial authors such as Haliburton, Dunlop, Moodie, Richardson, and John William Dawson were well known abroad, for their works had both British and American imprints. We know that Haliburton's The Clockmaker (1836) was pirated by both British and American publishers after its first publication in Nova Scotia. Did this situation point a moral to colonial authors? Were they inclined to publish abroad, not only for economic and career reasons, but in order to protect their copyrights? I don't have answers for these questions, except to refer you to Haliburton's subsequent publishing activities and to point out that the 1842 Imperial Literary Copyright Act did nothing to protect a colonial book outside the colony where it was first published.

These questions, however, did occur to colonial writers. For instance, one of the earliest analyses of the relation between literary property, professional authorship, and copyright legislation appeared in the September 1852 issue of The Provincial: or Halifax Monthly Magazine. Having first summarized the state of international copyright as it affected the United States and Britain, the writer then concentrates on the "hopeless condition" in which colonial literature has been placed by the Imperial Copyright Laws. Since it was generally accepted that American piracy had hurt the American author, the writer describes a similar situation to the north, where he gives the example of the New Brunswick author who has local protection but who can still be pirated in other British territories: 
We leave the reader to imagine the brilliant prospects of profit, which such an author or his publisher must have, with the whole of New Brunswick as the market prescribed by law for his work, and with the comforting conviction that the same work may be published and sold by others on every side of him - not only in Great Britain and, what are in all respects, foreign countries, but also in each of the neighbouring Provinces - without his having the power to prevent it; and that these - to him - foreign publishers may sometimes sell the work in New Brunswick in spite of him. We also leave the reader to imagine what amount of capital he would be likely to invest in publishing the work in question, under these circumstances. ${ }^{62}$

This writer (who is perhaps the editor, M.J.K.) proposes that the Provinces agitate for an inter-provincial copyright. He even sees this problem as one of the many arguments for a legislative union of British North America. He concludes with a representative mid-century view of the need for a native literature:

... whilst we have not a literature of our own, we can never have a feeling of nationality, with its concomitants of patriotism and due self-respect, we can never have any great moral weight among the civilized nations of the world, nor can we ever have a just conception of the moral position which we ought to hold among those nations. ${ }^{63}$

In the next issue of The Provincial, for October 1852, there was a favourable review of the American edition of Mrs. Moodie's Roughing It in the Bush. We can guess, therefore, which edition of Roughing It that Maritime readers were going to buy.

GEORGE L. PARKER

62“International Copyright," The Provincial; or Halifax Monthly Magazine, I (September $1852), 324$.

63 Ibia., 325. 